\title{
Seznanjenost javnega in zasebnega sektoria z ukrepi odprave administrativnih ovir v Sloveniji
}

UDK: 658:35(497.4)

Urška Milavec

urskamilavec1@gmail.com

Maja Klun

Univerza v Ljubljani, Fakulteta za upravo

maja.klun@fu.uni-lj.si

\section{IZVLEČEK}

Ukrepi odprave administrativnih ovir so del ukrepov izboljšanja kakovosti regulative. Z raziskavo, opravljeno leta 2010 tako $v$ javnem kot zasebnem sekłorju, smo želeli preveriti, ali ukrepe javni in zasebni sektor različno zaznavata ter ugotoviti, ali oba sektorja opredeljujeta isto skupino regulative kot najboli obremenilno. Rezultati so pokazali, da je informiranost o ukrepih odprave administrativnih ovir v Sloveniii slaba, posebej v zasebnem sektorju, ki naj bi bil glavni deležnik teh ukrepov. Kljub temu zasebni sekłor ugotavlja, da se je regulativa za mala in srednje velika podjetja izboljšala $v$ času izvajanja ukrepov odprave administrativnih ovir. Javni sektor regulativo s področja javnih naročil ocenjuje kot najbolj obremenjujočo, medtem ko zasebni sektor na prvo mesto uvršča regulativo s področja zaposlovanja.

Ključne besede: administrativne ovire in bremena, administrativnih stroški, konkurenčnost, informiranost, javni in zasebni sektor, Slovenija

JEL: H83, K2, K3

\section{Uvod}

Pojem regulativa $v$ najširšem pomenu označuje poti, $s$ pomočjo katerih se odloča in uvajajo odločitve javnega pomena. Najbolj splošno pa se pojem regulativa uporablja kot pojem, ki označuje doseganje ciljev

Milavec, U. \& Klun, M. (2011). Seznanjenost javnega in zasebnega sektorja

z ukrepi odprave administrativnih ovir $v$ Sloveniii.

Uprava, IX(1), 7-23. 
Urška Milavec, Maja Klun

Seznanjenost javnega in zasebnega sektorja z ukrepi

odprave administrativnih ovir v Sloveniji

javnega sektoria z uporabo pravil ali standardov (Hood et al., 2000). Kadar regulativa povzroča učinke, ki presegajo javni namen, govorimo o administrativnih ovirah. Prvi ukrepi na področju odprave administrativnih ovir (OAO) v Sloveniji so se začeli leta 2000 s tako imenovanim "antibirokratskim programom". Ukrepi so bili logična posledica vrste ukrepov in raziskav, ki so se pojavile v svetu. Poleg OECD in Evropske komisije, je bilo aktivnih kar nekaj skupin kot je SCM Network (mednarodna skupina, ki deluje na področju izmenjave najboljših praks, izkušeni in znani med državami in tako želi doseči svoj cili, ki je zmanjšanje administrativnih bremen in odstranitev nepotrebne birokracije) ali mreža višjih uradnikov, ki dela na področju boliše pravne ureditve $v$ svojih državah in ima svoj forum za izmenjavo najboljših praks pri oblikovanju novih predpisov (primarna in sekundarna zakonodaja). Pomembnejše raziskave administrativnih ovir pa so bile izvedene $v$ okviru Evropske banke za obnovo in razvoi z raziskavo, imenovano BEEPS (Business Environment and Enterprise Performance Survey), Svetovna banka z WGI (Worldwide Governance Indicators - svetovni kazalniki upravljanja), indeks svetovne konkurenčnosti - IMD, ki ga meri švicarski center za konkurenčnost, raziskava OECD s področja kakovosti institucii in administrativnih stroškov (OECD, 2001) ter nekatere druge parcialne raziskave s tega področja (Radaelli \& DeFrancesco, 2007; Brunetti et al., 1998; Chittenden et al., 2003; Massey, 2003, itd.). Skupna vsem študijam je ugotovitev, da kakovost institucij in regulative pomembno vplivata na konkurenčnost podjetij in gospodarstva.

Kot smo že omenili, so se prvi ukrepi v Sloveniji začeli s predstavitvijo tako imenovanega antibirokratskega programa. Prvo poročilo o poenostavitvi regulative je bilo objavlieno leta 2005. Potem je sledil akcijski načrt, imenovan "Program ukrepov za odpravo administrativnih ovir", ki je vsako leto predstavljen na vladnih spletnih straneh. Leta 2005 je bilo $v$ poročilu predstavljenih 40 ukrepov, ki pa niso bili finančno ovrednoteni. Napredek je bil prikazan šele v poročilu za leto 2006, ko so bili nekateri od ukrepov tudi finančno ocenjeni (npr. letni prihranki lokalnih skupnosti za nekatere javne storitve, potem tudi to, da lahko upravni uradi overijo podpis na nekem potrdilu, ki je enakovreden overitvi notarja, ...). V akcijskem načrtu 2006 je bilo sprejetih 34 ukrepov (92\% ukrepov je bilo realiziranih do oktobra 2008), v letu 2007 pa 30 ukrepov (realiziranih je bilo $60 \%$ ukrepov do oktobra 2008), zlasti na področju tako imenovanih življenjskih dogodkov, ki so pomembni za podjetja in 
državljane. Model za merjenje administrativnih stroškov EMMAS (enotna metodologija za merjenje administrativnih stroškov) je bil dokončno razvit konec julija 2007. V poročilu, objavljenem leta 2008, je bil prikazan skupni pregled izvedenih ukrepov za obdobje 2006-2008 in podana je bila skupna ocena prihranka administrativnih stroškov, narejena $\mathrm{s}$ pomočjo enotne metodologije in ocenjena za večino ukrepov. Iz meritev izhaja, da je bilo z realizacijo ukrepov, doseženo preko 100 mio $€$ prihrankov oziroma poenostavitev (npr. na področju registracije podjetij na točkah e-VEM se je prihranilo preko 10 mio $€$ na letnem nivoju, poenostavili so se postopki za mala podjetja na področju varstva osebnih podatkov, kjer prihranek znaša 36 mio € na leto, npr. ukinitev obrtnih dovoljeni za preko 60 gospodarskih dejavnosti, ...). V letu 2008 je bilo sprejetih 44 ukrepov, ki so bili vsi realizirani. Akcijski načrt, ki ga je potrdila vlada maja 2009 (sprejet je bil na podlagi mednarodnih zavez, gre za realizacijo cilja, da bo Slovenija, tako kot druge države članice EU, znižala administrativna bremena za $25 \%$ do leta 2012), vključuje v prvem delu 41 hitrih ukrepov na različnih področjih ureditve (dela, davkov, okolja, ...), ki so rezultat predlogov državljanov, podjetnikov in različnih zbornic (Ministrstvo za javno upravo, 2009) in v drugem delu sistematično merjenje administrativnih stroškov izbranih predpisov z uporabo enotne metodologije, ki izhaja iz metode SCM (Standard Cost Mode). Junija 2010 je Vlada Republike Slovenije sprejela "Načrt aktivnosti za skrajševanje postopkov in odpravo administrativnih ovir", ki se osredotoča na 6 področij zakonodaje (pridobitev gradbenega dovoljenja, delovno pravna zakonodaja, plačevanje davkov in prispevkov, prenos lastništva, mednarodno poslovanje in izvrševanje pogodb).

Poseben poudarek je dan tudi presoji učinkov regulative - PUR (Regulatory Impact Analysis - RIA), ki jo je Slovenija leta 2007 vsaj na formalni ravni uvedla $\vee$ naš pravni red (sprememba 8. člena vlade RS Ur. I. RS, št. 43/2001, 21/2007). Gre za pravne vidike analize učinkov predpisov od leta 2002. V letu 2007 je OECD poročal, da Slovenija kaže veliko izboljšav na področju zmanjševanja administrativnih ovir, vendar je treba izboljšati presojo učinkov regulative. Na slednje je $v$ poročilu opozoril tudi varuh človekovih pravic. $\vee$ mesecu novembru 2009 je bila $\vee$ Državnem zboru sprejeta Resolucija o normativni dejavnosti (UL RS, št. 95/2009), ki je akt programske narave in je politično zavezujoč dokument, pripravljen $v$ skladu z obstoječimi pravnimi predpisi, ki določajo postopek sprejemanja predpisov. Resolucija se nanaša na širše 
Urška Milavec, Maja Klun

Seznanjenost javnega in zasebnega sektorja z ukrepi

odprave administrativnih ovir v Sloveniji

področje normativne dejavnosti, katere nosilci so vlada, ministrstva in drugi organi (nosilci javnih pooblastil in organi lokalnih skupnosti) kot celote. Resolucija povzema ustaljena ustavna, pravno-sistemska in nomotehnična načela in pravila, hkrati pa naj bi pomenila zavezo vsakokratne politične oblasti in javnih uslužbencev, da bodo pri oblikovanju politik in pripravi predpisov upoštevali glavna načela dobre zakonodajne politike. Pripravljavci predpisov in politik bodo morali vestno izvajati presoje posledic predlogov predpisov in politik na gospodarstvo, okolje, socialo in na javne finance oziroma širši segment javne uprave ter $v$ skladu z minimalnimi priporočili in smernicami sodelovati s strokovno in z drugimi zainteresiranimi javnostmi. Na podlagi resolucije je bila junija 2010 sprejeta sprememba poslovnika vlade, skupaj z navodili za pripravo vladnih gradiv. Da bi bilo izvajanje programa za odpravo administrativnih ovir oziroma zmanjševanje administrativnih bremen učinkovito, ta navodila vsebujejo zahtevo po presoji učinkov novega ali spremenjenega predpisa. Tako morajo resorji posebno pozornost nameniti presoji učinkov in opredeliti vplive na posamezna področja, med drugim morajo jasno zapisati tudi vpliv na administrativne obremenitve/razbremenitve.

Iz navedenega je razvidno, da se večina raziskav osredotoča na merjenje administrativnih stroškov regulative in $s$ tem iskanja najbolj obremenjujočih dejavnikov posamezne regulative ter tako iskanja možnosti za poenostavitve. Po drugi strani raziskave ugotavljajo najboli obremenjujočo regulativo $\mathrm{z}$ vidika konkurenčnosti gospodarstva in razvrščajo države $v$ določene lestvice. Uspehi različnih ukrepov se ponavadi kažejo $v$ napredovanjih države po različnih lestvicah, bolj specifično pa $\vee$ poročilih pristojnih organov $v$ različnih državah o izvedenih in doseženih poenostavitvah regulative.

V prispevku želimo prikazati drugi vidik, ki ni pogost v raziskavah, in sicer seznanjenost javnosti z uspehi in ukrepi na področju odprave administrativnih ovir. $\vee$ okviru raziskave smo skušali preveriti dve trditvi. Prva je, da se seznanjenost o projektu odprave administrativnih ovir (v nadaljevanju $\mathrm{OAO}$ ) ne razlikuje med zasebnim in javnim sektorjem. Druga trditev pa je, da zasebni in javni sektor različno ocenjujeta obremenitev posameznih področii regulative. S tem smo želeli oceniti uspešnost ukrepov odprave administrativnih ovir. To pomeni, da v kolikor ukrepi niso bili zaznani tudi v praksi, niso bili dovolj ciljno usmerjeni. Pri tem smo javnost razdelili na dve skupini, in sicer na javni in zasebni sektor. $\vee$ nadaljevanju najprej sledi poglavje o ugotovitvah različnih 
avtorjev in raziskav o povezanosti kakovosti regulative s konkurenčnostjo gospodarstva. Potem sledi opredelitev raziskave, metodologije in rezultatov.

\section{Pomembnost odprave administrativnih ovir za konkurenčnost gospodarstva}

Na pomladanskem vrhu marca leta 2000 so voditelii držav članic EU sprejeli Lizbonsko strategijo, ki predvideva, da bi EU do leta 2010 postala najboli dinamično, konkurenčno ter na znanju temelječe gospodarstvo na svetu. Izbolišanje konkurenčnosti podjetij je tudi eden od temeljnih ciljev slovenske strategije razvoja (Vlada RS, 2010). V okviru "novega začetka za Lizbonsko strategijo" je Svet EU marca 2005 objavil obvestilo o širših smernicah ekonomske politike ter poudaril posebno smernico (št. 14) o kakovosti zakonodaje, sistematičnem ocenjevanju administrativnih stroškov in koristi ter zmanjševanju administrativnih bremen za podjetja (Council of the European Union, 2005, str. 23-24). Cilia te smernice sta z bolišo zakonodajo ustvariti boli konkurenčno poslovno okolje in spodbujanje zasebnikov. Štiri leta prej (leta 2001) je bilo v Mandelkernovem poročilu (načrt za boljšo pravno ureditev, ki so ga sestavili ministri za javno upravo) $\vee$ povzetku zapisano, da je izboljšanje kakovosti zakonodaje javno dobro že samo po sebi, saj krepi (povečuje) verodostojnost vodenja procesa in prispeva k blaginji državljanov. Projekt odpravljanja administrativnih ovir in birokratskih postopkov ter načrtnega zmanjševanja administrativnih bremen, predvsem usmerjen $v$ gospodarstvo, je ključen element teh prizadevani, saj podjetja in posameznike $v$ državah članicah rešuje pretirane regulative in odvečne birokracije ter s tem osvobaja energijo za podjetniško aktivnost, inovacije in državljansko vključenost (Mandelkern, 2001).

Na ravni EU so aktivnosti usmerjene v "čiščenje" že sprejetih predpisov in izbolišanje postopkov sprejemanja novih predpisov. Tako imenovano čiščenje starih predpisov se izvaja v okviru dveh projektov. Prvi se nanaša na poenostavitev predpisov, drugi pa na zniževanje administrativnih bremen oziroma odpravljanje administrativnih ovir. Cilj obeh projektov je poenostaviti in predvsem "debirokratizirati" zakonodajno okolje in s tem prispevati k znižanju stroškov. Poseben poudarek je namenjen malim podjetjem in v okviru te skupine predvsem mikronivoju (Zatler, 2009).

Kakovost regulative vključuje razvoi boljših neregulatornih instrumentov in večjo preglednost (Klun \& Slabe-Erker, 2009). Pojem 
"boljši predpisi" vključuje vrsto ukrepov javnih politik, ki so namenjeni krepitvi sposobnosti institucii, da le-te izvajajo visoko kakovostno regulativo (Radaelli, 2007; Virant \& Kovač, 2010; Virant, 2010). V Mandelkernovem poročilu (2001) je $v$ povzetku tudi zapisano, da izvajanje Akcijskega programa in drugih ukrepov pomembno prispeva $\mathrm{k}$ povečanju konkurenčnosti evropskega gospodarstva in dobremu počutju državljanov ter $k$ večji verodostojnosti in legitimnosti vlade. $V$ poročilu OECD (1997) so predstavljeni "novi načini" regulative, in sicer stroškovna učinkovitost, sodelovanje javnosti, pristop od spodaj navzgor, fleksibilnost, dinamičnost, odzivnost itd.

Regulativa nikoli ne sme biti sama sebi namen, ampak mora biti vedno sredstvo za zagotavljanje javnega interesa ali doseganje javnega cilja. $\vee$ zadnjih nekaj desetletjih je sistem pravil $\vee$ številnih državah postal boli zapleten, zaradi česar podjetja in posamezniki ne razumejo vedno logike nekega pravila. Kot že omenjeno, regulativa pogosto zahteva izpolnjevanje določenih obrazcev, ki je včasih nepotrebno, zamudno ter drago. Zato morajo vse države ustvariti najboljše možne pogoje za poslovanje podjetij z državno upravo. Država mora torej vzpostaviti neko ravnotežje (SCM Network, 2010). V Sloveniii je v praksi precej napotil na druge člene in predpise, npr. na področju davčne zakonodaje je rekorder Zakon o dohodnimi (ZDoh-2, Ur. I. RS, št. 117/2006), saj o povprečenju dohodkov samo $v$ treh odstavkih napotuje na 25 členov istega zakona, mnogi od nịh pa napotujejo naprei (kaskadno napotovanje).

Evropska komisija (2009a) je objavila pravila pisanja predpisov, ki zahteva, da naj bodo ti:

- jasni, razumliivi, enostavni, nedvoumni;

- uporabliajo naj se $v$ večji meri izrazi, ki se uporabljajo tudi v pogovornem jeziku;

- terminologija naj bo koherentna, isti pojmi v povezanih zakonih pa enaki;

- napotovanje na druge predpise naj bo minimalno, prav tako se je treba izogniti navzkrižnemu napotovanju (člen na člen).

Najboli razvite države članice EU so se projektov za odpravljanje administrativnih ovir in poenostavitev zakonodajnega okolja lotile že bistveno pred Evropsko komisijo. Tako je Nizozemska razvila metodologijo za merjenje administrativnih stroškov (metodologija SCM), v

12 Uprava, letnik IX, 1/2011 
letu 2005 pa jo je za delo pri zniževanju administrativnih stroškov prevzela tudi Evropska komisija. Poleg Nizozemske so pomembne aktivnosti potekale tudi $v$ Veliki Britaniji in na Danskem. S sprejetjem akcijskega programa $\vee$ smeri minus 25 na ravni EU se je sprožil val aktivnosti tudi $v$ drugih državah članicah. Na Nizozemskem so administrativni stroški ocenjeni na 16,4 milijard evrov letno. To ustreza $3,6 \%$ bruto domačega proizvoda. Na Danskem je celoten znesek administrativnih bremen ocenjen na približno 4,5 milijarde evrov, kar ustreza 2,4 odstotkom BDP (SCM Network, 2010). V Sloveniii ta delež znaša 4,1 \% BDP, kar škoduje konkurenčnosti gospodarstva. Če bi v celoti izvedli projekt $\mathrm{OAO}$, bi lahko celotni prihranki za gospodarstvo znašali od 2 do 3,5\% slovenskega BDP (Zatler, 2009). To je glavni razlog, zakaj je pomembno, da se vlade osredotočijo na zmanjševanje administrativnih stroškov za podjetja in tudi državljane. Ekonomska perspektiva torej daje poudarek na uspešnosti in učinkovitosti z minimalnimi sredstvi (stroški). Z ekonomskega vidika je odprava administrativnih ovir ključnega pomena za konkurenčnost gospodarstva, saj omogoča porabo sredstev za inovacije, utriuje konkurenčnost in izboljšuje ekonomsko učinkovitost in uspešnost. Nekateri empirični poskusi so pokazali pozitiven vpliv kakovostne regulative na gospodarsko rast, merieno z BDP na prebivalca (Jalilian et al., 2007).

Komisija je sprožila vseevropski projekt (mani birokracije), da bodo podjetja $\vee$ EU bolj konkurenčna. Od sedmih držav članic ob koncu leta 2006 je sedaj vseh 27 določilo ambiciozne cilje za zmanjšanje obremenitev, ki izhajajo izključno iz nacionalnih predpisov. Aktivnosti za zniževanje bremen so na nacionalni ravni nujne, saj $v$ nasprotnem primeru enotnega evropskega cilja ni mogoče doseči. Aktivnosti EU in tudi posameznih držav članic potekajo $v$ več segmentih. Tako se na eni strani izvajajo ukrepi za spremembo že obstoječe zakonodaje, in sicer gre za projekt zniževanja administrativnih bremen in odprave administrativnih ovir na posameznih prioritetnih področjih, na drugi strani pa se izvajajo aktivnosti sistematičnega merjenja administrativnih stroškov in preverjanja zakonodaje $v$ postopku njenega sprejemanja (European Commission, 2010). Komisija je že opredelila mogoča zmanjšanja bremen. Ukrepi, ki jih je sprejela in nekatere tudi že uvedla (48 ukrepov $=6 \%$ ), bi prinesli znižanje $\vee$ višini 7,6 milijard evrov. Ukrepi, ki jih je Komisija predlagala (18 ukrepov $=25 \%$ ), bi lahko prinesli 30,7 milijard evrov prihrankov. Pripravljalna dela za nadaljnje zmanjševanje administrativnih obremenitev 
bi lahko privedla do predložitve dodatnih 31 -ih ukrepov (2 \%), kar prinaša dodatno zmanjšanje $v$ višini najmani 2,1 milijardi evrov. Vse to bi torej pomenilo zmanjšanje administrativnih obremenitev za 40,4 milijard evrov od zmerjenih 123,8 milijard evrov. To je $33 \%$ zmanjšanje celotne ocenjene obremenitve evropske zakonodaje (European Commission, 2009b, str. 6).

\section{Predstavitev raziskave}

\subsection{Predstavitev vprašalnika in vzorec}

$\checkmark$ nadaljevanju je predstavljena raziskava, ki je bila izvedena $\mathrm{v}$ Sloveniji. Podobna raziskava o odmevnosti ukrepov $v$ tujini ni bila izvedena, čeprav države $v$ svojih poročilih omenjajo, da se pri odpravi administrativnih ovir posvetujejo z javnostjo ali pa je le-ta vključena $v$ sam postopek. Na pomanjkanje podobnih raziskav opozarjajo predvsem delovne skupine $v$ različnih državah, ki bi želele učinke ukrepov oceniti tudi s tega vidika (SCM Network, 2010).

$\checkmark$ raziskavo $v$ Sloveniji sta bila vključena zasebni sektor (podjetja) in javni sektor (javni uslužbenci). Z vsebinsko enotnim vprašalnikom smo želeli ugotoviti razlike, ki se pojavljajo pri zaznavanju problematike administrativnih ovir in seznanjenosti z ukrepi na tem področju. Vprašalnik je bil sestavljen iz 13 medsebojno povezanih vprašanj. Prvi sklop vprašani je bil namenjen pridobivanju osnovnih podatkov o anketirancih (kateri del javnega sektorja predstavlja anketirani oziroma velikost podjetja), sledilo je vprašanje o seznanjenosti z ukrepi odprave administrativnih ovir in pomembnosti teh ukrepov ter aktivnost anketirancev pri sodelovanju. Sledila so vprašanja o zaznavanju ovir in definiranju področij, kjer so ovire najboli zaznane.

Obe ciljni skupini sta bili anketirani z anketo po e-pošti. Anketa javnih uslužbencev je bila izvedena z vprašalnikom, poslanim preko elektronske pošte na centralne naslove vseh organov državne uprave in občin, od koder je bil vprašalnik poslan v e-poštne nabiralnike vseh zaposlenih. Poslanih je bilo 306 vprašalnikov. Prejeli smo 197 vrnjenih vprašalnikov, z vsemi podanimi odgovori je bilo 90 vprašalnikov, zato se število odgovorov pri posameznih vprašaniih razlikuje.

Elektronska anketa podjetii je bila izvedena aprila 2010 z uporabo spletnega programa za izvajanje anket na vzorcu 600 podjetij v štirih

14 Uprava, letnik IX, 1/2011 
reprezentativnih velikostnih skupinah: velika podjetja, srednje velika podjetja, majhna podjetja, s.p.-ji in mikro podjetja. Od tega se je odzvalo 125 vprašanih, popolnoma veljavnih pa je bilo le 82 vprašalnikov. Največ podjetii, ki so izpolnili anketo, spada $v$ tretji razred, kjer je število zaposlenih med 10 in 50 (37\%), torej gre za mala podjetja, nato sledi drugi razred (27\%), kjer je zaposlenih do 9 ljudi, najmani podjetii pa je zastopanih $\vee$ petem razredu (2\%), kjer je število zaposlenih nad 250. Struktura realiziranega vzorca je torej zadovoljiva glede na strukturo $v$ celotni populaciji. Cilina oseba je bil v velikih in srednjih podjetjih vodja splošnega sektorja, $v$ malih in mikro podjetiih ter s.p.-jih pa direktor. $V$ primeru nedosegliivosti je lahko anketo izpolnila tudi druga odgovorna oseba. Vzorčenje je potekalo na podlagi metode iskanja kvot, zato je vzorec reprezentativen samo znotraj posameznih velikostnih skupin in upošteva ustrezno porazdelitev dejavnosti in regionalno zastopanost.

Vsi rezultati so podani $\vee$ obliki deležev (\%) ali srednih (povprečnih) vrednosti odgovorov. $V$ slednjem primeru so anketiranci posamezne možnosti ocenjevali na lestvici od 1 do 5, pri čemer je 1 vedno pomenila najslabšo oceno (popolnoma nepomembno), ocena 5 pa je vedno pomenila najboljšo oceno (popolnoma pomembno).

\subsection{Rezultati raziskave}

Kot je že omenjeno $v$ uvodu, želimo predstaviti rezultate tistega dela raziskave, $v$ katerem smo ocenili seznanjenost obeh sektorjev z ukrepi in določanjem področii zakonodaje, za katere posamezni sektor meni, da povzročajo najvišje administrativne ovire.

Na vprašanje o tem, ali so anketiranci že slišali za projekt odprave administrativnih ovir, je pritrdilno odgovorilo le $38 \%$ podjetii, medtem ko je seznanjenost $v$ javnem sektorju višja, saj je pritrdilno odgovorilo $70 \%$ vprašanih. $\bigcirc$ ukrepih odprave administrativnih ovir je torej seznanjena le dobra tretjina zasebnega sektorja, čeprav je večina ukrepov namenjenih prav zasebnemu sektorju. Naslednje vprašanje je bilo kontrolno in povezano s prvim vprašanjem, in sicer ali so anketiranci seznanjeni s cilji in ukrepi projekta OAO. Iz grafikona 1 je razvidno, da tudi tisti anketiranci zasebnega sektorja, ki so za projekt že slišali, le-tega ne poznajo dobro, saj je dobro seznanjenih le $9 \%$ anketiranih podjetii, medtem ko zelo dobre seznanjenosti ni označil noben anketirani iz zasebnega sektorja. Podrobnejša seznanjenost s cilji in ukrepi $O A O$ je slabša tudi $v$ javnem sektorju, saj je dobro ali zelo dobro seznanjenih 
s cilji in ukrepi le $40 \%$. Glede na to, da ta projekt poteka že od vstopa Slovenije $v E U$, so rezultati pokazali na slabo informiranost anketirancev s cilji in ukrepi, ki se želijo doseči v okviru tega projekta $v$ obeh sektorijh. Kar tretjina vprašanih $v$ poslovnem sektorju zelo slabo pozna vsebino (bistvo) tega projekta, tudi $21 \%$ vprašanih v javnem sektorju je enakega mnenja.

\section{Grafikon 1: Seznanjenost s cilji in ukrepi projekta OAO}

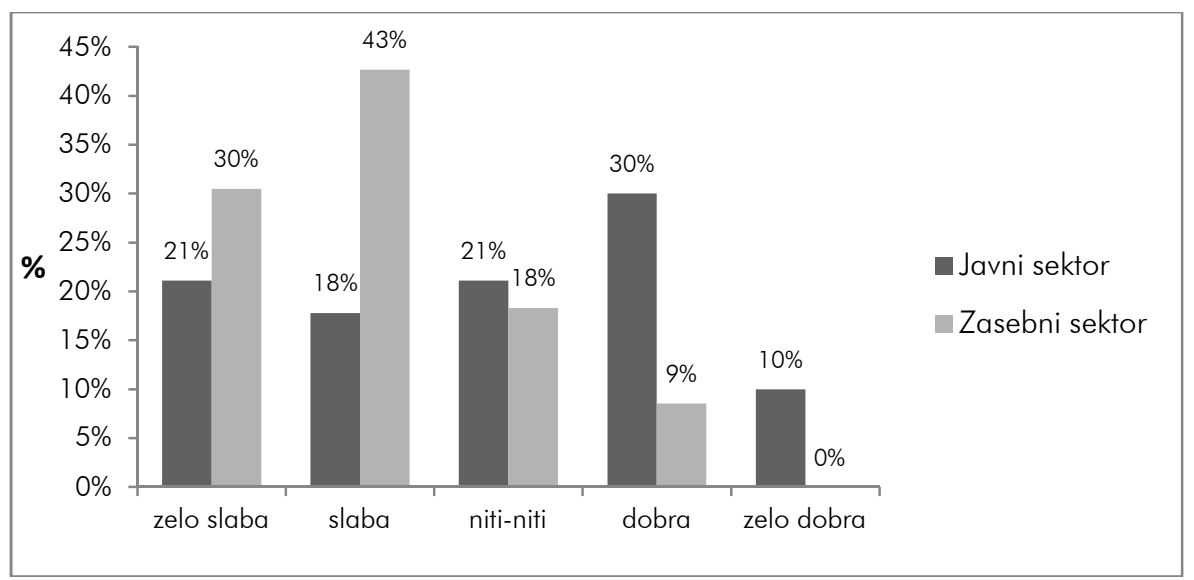

Vir: anketa

Slaba seznanjenost s cilii in ukrepi ter samim projektom OAO kot celoto se kaže tudi $v$ neaktivnosti deležnikov za sodelovanje pri tem projektu. Na vprašanje o tem, ali so anketirani že kdaj predložili svoje predloge za odpravo administrativnih ovir, je večina odgovorila negativno. Predloge je tako podalo le 3,7\% anketiranih zasebnega sektorja in $16,7 \%$ v javnem sektorju.

Večina zasebnega in javnega sektoria meni (v povprečju $63 \%$ v obeh skupinah), da jih obstoječa zakonodaja ovira pri poslovanju. Vendar struktura odgovorov znotraj zasebnega sektorja kaže, da to mnenje prevladuje predvsem v manjših podjetjih, saj tako meni kar $38 \%$ malih in $29 \%$ mikro podjetii (odgovori zelo ovira), medtem ko je mnenje 'zelo ovira' izpostavilo le $5 \%$ velikih podjetij. Nobeno od vprašanih podjetii pa ni menilo, da ga zakonodaja ne ovira.

$\checkmark$ okviru raziskave smo želeli preveriti tudi, ali javni in zasebni sektor različno zaznavata rezultate ukrepov $O A O$, posebej $v$ tistem delu, ki se nanaša na zniževanje administrativnih stroškov zakonodaje. Zanimivo je, da večina anketiranih meni, da so se stroški v zadnjih treh letih povečali.

16 Uprava, letnik IX, 1/2011 
Kljub temu pa zasebni sektor zaznava tudi zniževanje administrativnih stroškov, kar pomeni, da se nekateri rezultati že kažejo (struktura odgovorov je podana $v$ tabeli 1). Podrobnejša analiza odgovorov kaže, da zniževanje administrativnih stroškov zaznavajo samo mikro in majhna podjetja ter samostojni podjetniki posamezniki, medtem ko srednje velika podjetja in velika podjetja tega odgovora niso označila. Ker je večina ukrepov dejansko usmerjena k majhnim in srednje velikim podjetjem, je ta odgovor tudi pričakovan. Ocenimo lahko, da se nekateri učinki ukrepov OAO že zaznavajo v zasebnem sektorju, čeprav v majhnem obsegu.

\section{Tabela 1: Gibanje administrativnih stroškov izpolnjevanja predpisov $v$ zadnjih} 3 letih

\begin{tabular}{|l|r|r|}
\hline Gibanje stroškov & Zasebni sektor (\%) & Javni sektor (\%) \\
\hline Zelo povečali & 8,5 & 11,1 \\
\hline Povečali & 64,6 & 51,1 \\
\hline Ostali enaki & 11,0 & 18,9 \\
\hline Znižali & 1,2 & 0 \\
\hline Precej znižali & 1,2 & 0 \\
\hline Ne vem & 13,4 & 18,9 \\
\hline
\end{tabular}

Vir: anketa

$\mathrm{V}$ okviru stroškov, povezanih $\mathrm{z}$ izpolnjevanjem predpisov, so pomembni tudi razlogi za povečevanje stroškov. Največ anketirancev $v$ obeh sektoriih meni, da se stroški povečujejo zaradi nenehnih sprememb predpisov (grafikon 2). To meni 67,1 \% vprašanih v zasebnem sektoriu in $75,6 \%$ vprašanih $v$ javnem sektorju. Nepotrebno obremenjena poslovna administracija je običajno zelo povezana s prilagajanjem na novo ureditev. Drugi najpomembnejši razlog, da se stroški povečujejo, je po mnenju anketirancev številčnost predpisov. To meni $63,3 \%$ anketiranih $v$ javnem sektorju in 58,5\% anketiranih $v$ zasebnem sektorju. Kot razloga sledita še zapletenost in nejasnost predpisov. 


\section{Grafikon 2: Razlogi za povečevanje stroškov predpisov}

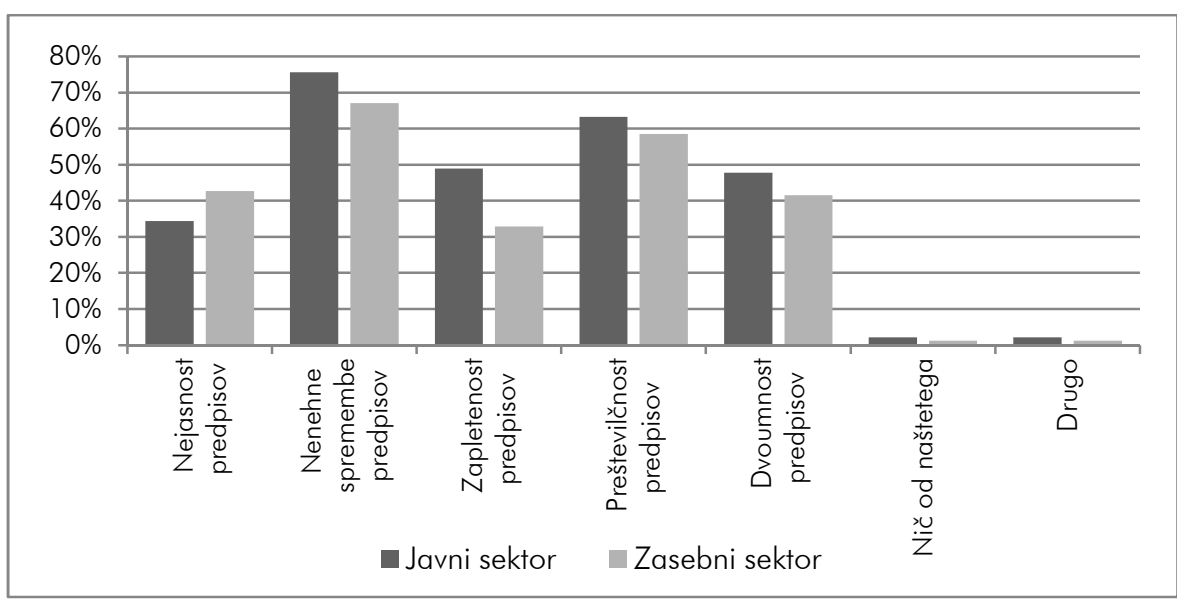

Vir: anketa

Čeprav so ukrepi OAO transparentno prikazani na spletnih straneh Ministrstva za javno upravo, iz raziskave izhaja, da je seznanjenost javnosti relativno slaba. Ukrepov za večjo odmevnost je lahko več, in sicer boliše obveščanje o ukrepih predvsem $\vee$ ustreznih združenjih zasebnega sektorja, boliša promocija $v$ medijih, poročilih o delovanju ipd. Največji učinek bi dosegli z večjo vključenostjo obeh sektorjev $v$ sam projekt. Tako meni tudi večina anketiranih, ki so $z$ visokimi ocenami ocenjevali trditve o tem, da bi morala biti $\vee$ projekt vključena širša javnost oziroma zainteresirane skupine pri določenih sklopih regulative neposredno, ne pa samo s samoiniciativnimi predlogi na spletni strani ministrstva. Kot drugi najboli visoko ocenjeni predlog za izboljšanje učinkov ukrepov in tudi seznanjenosti pa oba sektorja vidita v tem, da bi se morali projekti OAO izvajati kot povezani sklopi v okviru posameznih poslovnih dogodkov.

Evropska komisija in podobno tudi Slovenija sta določili 13 prioritetnih področij regulative, ki so najbolj obremenilna. $V$ raziskavi smo želeli preveriti, ali sektorja različno zaznavata obremenitev posameznih področij regulative, oziroma na katerem področju si želijo največ izvedenih ukrepov za poenostavitev (grafikon 3). Najslabši rezultat je $v$ zasebnem sektoriu doseglo področje delovnih razmerii, kar meni kar $62,2 \%$ vseh vprašanih podjetii. To so pokazale tudi druge raziskave (npr. glei Klun \& Slabe-Erker, 2008), zato so se v Sloveniji sistematičnega znižanja administrativnih stroškov po modelu SCM lotili najprej na področju delovnopravne zakonodaje, s sprejetjem prvega akcijskega programa. Program naj bi bil realiziran do konca leta 2010. Med 
anketiranci $v$ zasebnem sektorju je na drugem mestu področje prava družb in letnih računovodskih izkazov. To meni $58,5 \%$ podjetii. Tudi javni sektor v sam vrh uvršča delovno zakonodajo $(45,6 \%)$, vendar javni sektor kot najbolj obremenjujočo zakonodajo na prvo mesto uvršča področje javnih naročil $(62,2 \%)$.

\section{Grafikon 3: Razlogi za povečevanje stroškov predpisov}

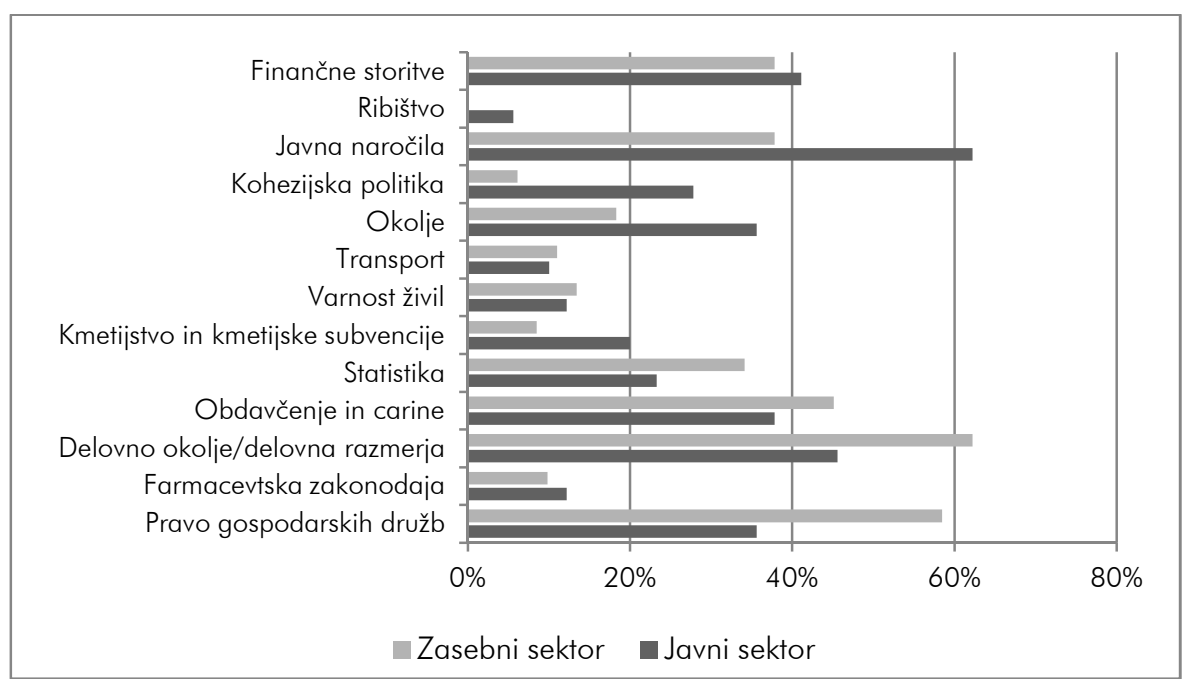

Vir: anketa

Sami rezultati raziskave so pričakovani. Nefleksibilnost delovne zakonodaje je znan problem slovenske zakonodaje. Regulativa na tem področju je $\vee$ Sloveniji precej kompleksna. Z regulativo so določeni vsi pomembni postopki zaposlovanja, in sicer razpisi prostih delovnih mest, obveščanje ustreznih organov o zaposlovanju, vodenje ustreznih evidenc, omejeno trajanje zaposlovanja za določen čas, visoki stroški delovne sile, določanje minimalne plače itd. $\vee$ javnem sektorju so omejitve večje, saj so predvsem $v$ državni upravi določene sistemizacije, plačni razredi, trajanje razpisov ipd. Velika konkurenčnost na trgu in nefleksibilnost regulative sili zasebni sektor $v$ omejeno zaposlovanje za nedoločen čas, reorganizacije, ki so vezane izključno na zamenjavo delovne sile ali umetnega podaljševanja zaposlitev za določen čas. Vsi taki ukrepi pomenijo neustrezno rabo resursov in zmanjšujejo produktivnost dela. Po drugi strani je regulativa s področja javnih naročil za javni sektor pričakovano med najbolj obremenjujočimi, saj je večina poslovanja javnega sektorja vezana na javna naročila, ki zahtevajo kompleksno vodenje postopkov in pripravo ustreznih razpisnih dokumentacii. Poudariti je treba tudi dejstvo, 
da je bila anketa izvedena neposredno $v$ času spremembe regulative na tem področju in je lahko na oceno vplivalo tudi to. Čeprav nova zakonodaja poenostavlja nekatere postopke, po drugi strani uvaja nove zahteve kot je npr. obvezno izobraževanja (licenca) in podpis pogodbe šele po preteku roka za pritožbe.

Odprava administrativnih ovir na obeh najbolj obremenjujočih področjih regulative za oba sektoria je mogoča, na kar kažejo tudi poročila o prvih merjenjih administrativnih stroškov na področju predvsem delovnopravne regulative (podrobneje glej Klun et al., 2008), medtem ko za področje javnih naročil merjenje ni bilo izvedeno.

\section{Zaključek}

Slovenija si že od leta 2001 dalje prizadeva za poenostavitev postopkov in boljšo zakonodajo, tako domačo kot tisto, ki je del evropskega pravnega reda. Ministrstvo za javno upravo na svoji spletni strani navaja in razlaga poti, ki vodijo $k$ poenostavitvam $v$ okviru odprave administrativnih bremen: (i) odstranitev, zmanjšanje, združevanje ali izbolišanje zakonodajnih predpisov, (ii) poenostavitev procesov znotraj zakonodajnih predpisov, (iii) izmenjava podatkov znotraj uprave, (iv) razvoi informacijsko telekomunikacijskih rešitev in storitev ter (v) zagotavljanje boljših navodil in informacij. Očitno je, da so se administrativna bremena $v$ evropskih in nacionalnih predpisih leta brezskrbno in nekritično kopičila. Če ni $v$ zadostni meri izoblikovana zavest pripravljavcev predpisov ali če niso vsaj vzpostavljeni kontrolni mehanizmi, se administrativna bremena neizogibno kopičijo. Največkrat so posledica birokratskega načina razmišljanja pripravljavcev predpisov, odsotnosti analize učinkov predpisov, zanemarjanja pomena dejanske izvedljivosti predpisa, pa tudi težnje birokracije po povečevanju moči. Edina rešitev za preprečevanje nastajanja administrativnih bremen in za odstranjevanje starih je resna politična zaveza. Politika je dolžna voditi in usmerjati javno upravo in brez njenih usmeritev je malo verjetno, da bo prišlo do sprememb $\vee$ načinu razmišljanja in ravnanja. $S$ pogostim merjenjem administrativnih stroškov in ocenjevanjem kakovosti predpisov in informacii ter ustreznimi časovnimi, področnimi ter mednarodnimi primerjavami rezultatov je treba zagotavljati, da bo smer ukrepa prava, v smislu ustreznosti, učinkovitosti in trajnosti. 
$\checkmark$ okviru raziskave smo ugotovili, da so različni deležniki ukrepov OAO še vedno slabo seznanjeni s projektom, čeprav zasebni sektor že zaznava rezultate. Zanimivo je, da oba sektoria ocenjujeta po pomembnosti enake razloge za nastanek administrativnih ovir, po drugi strani pa različno ocenjujeta najbolj obremenjujoča področja regulative. Iz rezultatov raziskave je razvidno, da bi bila potrebna aktivnejša promocija projekta $\mathrm{OAO}$ in $\mathrm{s}$ tem večja vključenost deležnikov $v$ sam projekt.

Urška Milavec je leta 2010 zaključila magistrski študij na Fakulteti za upravo.

Dr. Maja Klun je izredna profesorica na Fakulteti za upravo. Nieno primarno področje raziskovanja in znanstvenega ter strokovnega proučevanja so javne finance s poudarkom na davčnem sistemu, $k$ rezultatom usmerjeni proračun in merjenje učinkovitosti in uspešnosti javnega sektoria. 
Urška Milavec, Maja Klun

Seznanjenost javnega in zasebnega sektorja z ukrepi

odprave administrativnih ovir v Sloveniji

\section{Literatura in viri}

- Brunetti, A., Kisunko, G. \& Weder B. (1998). How Businesses See Government. Responses from Private Sector Surveys in 69 Countries. Discussion paper no. 33. New York: World Bank.

- Chittenden, F., Kauser, S. \& Poutziouris, P. (2003). Tax regulation and Small Business in the USA, UK, Australia and New Zealand. International Small Business Journal (21), 93-115.

- Council of the European Union. (2005). Integrated guidelines: broad economic policy guidelines. Document 10667/05. Brussels: Council of EU.

- European Commission. (2007). Communication from the Commission to the Council, the European Parilament, the European Economic and Social Committe and Committee of the regions. Action Programme for Reducing Administrative Burdens in the European Union. COM (2007) 23. Brussels: EC.

- European Commission. (2009a). Impact assessment guidelines. SEC(2009)92. Brussels: EC.

- European Commission. (2009b). Communication from the commission to the council and the european parliament. Action Programme for Reducing Administrative Burdens in the EU Sectoral Reduction Plans and 2009 Actions. COM (2009) 544 final. Brussels: EC

- European Commission. (2010). Enterprise and Industry. Better regulation. Action Programme for Reducing Administrative Burdens. Brussels: EC

- Jallilian, H., Krkpatrick, C. \& Parker, D. (2007). The Impact of Regulation on Economic Growth in Developing Countries: A Cross-country Analysis. World Development (35), 87-103.

- Klun, M. \& Slabe-Erker, R. (2008). Ocena administriranja, povezanega s predpisi na področju zaposlovanja. Podjetje in delo (34), 640-650.

- Klun, M. \& Slabe-Erker, R. (2009). Business views of the quality of tax, environment and employment regulation and institutions: the Slovenian case. International Review of Administrative Sciences (75), 529-548.

- Klun, M. et al. (2008). Ovrednotenje administrativnih ovir za povečanje konkurenčnosti podjetii. Ciljno raziskovalni program "Konkurenčnost Slovenije 2006-2013". Zaključno poročilo. Ljubljana: Fakulteta za upravo in IER.

- Mandelkern (Group on Better Regulation). (2001). Final Report. Brussels: EC. 


\section{Urška Milavec, Maja Klun \\ Seznanjenost javnega in zasebnega sektorja z ukrepi odprave administrativnih ovir v Sloveniji}

- Massey, C. (2003). The Impact of Business Compliance: Perceptions of New Zealand Firms. New Zealand Centre for Small \& Medium Enterprise Research, Massey University.

- Ministrstvo za javno upravo. (2009). -25\% - Program vlade Republike Slovenije do leta 2012. Ljubliana: MJU.

- OECD. (1997). The OECD Report on Regulatory Reform. Volume II: Thematic studies. Paris: OECD.

- OECD. (2001). Business' Views on Red Tape, Administrative and Regulatory Burdens on Small and Medium Sized Enterprises. Paris: OECD.

- OECD. (2009). Indicators of Regulatory Management Systems. Paris: OECD.

- Radaelli C. \& De Francesco F. (2007). Regulatory Quality in Europe Concepts, Measures and Policy Processes. Manschester: Manchester University Press.

- Radaelli, C. M. (2007). Whither Better Regulation for the Lisbon Agenda? Journal of European Public Policy (14), 190-207.

- Resolucija o normativni dejavnosti. Ur. I. RS, št. 95/2009.

- SCM Network. (2010). Why reduce administrative burdens? Pridoblieno 1. 1.2010, s http://www.administrativeburdens.com/default.asp? page $=239$

- Virant, G. \& Kovač, P. (2010). Reducing Administrative Burdens as Part of the "Better Regulation" Programme - the Case of Slovenia. Lex Localis (8), 369-393.

- Virant, G. (2010). Izboljšanje kakovosti regulacije - razvoj v Sloveniji. Uprava VIII(3), 113-134.

- Vlada Republike Slovenije. (2010). Načrt aktivnosti za skrajševanje postopkov in odpravo administrativnih ovir. Ljubljana: Vlada RS.

- Zakon o dohodnini. Ur. I. RS, št. 117/2006.

- Zatler, R. (2009). Odprava administrativnih ovir v publikaciji. Javna uprava (45), 287-299. 